\title{
Distance Education at Conventional Universities in Germany
}

\author{
Hans-Henning Kappel \\ Johann Wolfgang Goethe-University \\ Burkhard Lehmann \\ University of Kaiserslautern \\ Joachim Loeper \\ University of Koblenz-Landau
}

\begin{abstract}
Germany's educational system has undergone a series of transformations during the last 40 years. In recent years, marked increases in enrolment have occurred. In response, admission requirements have been relaxed and new universities have been established.

Academic distance education in the former Federal Republic of Germany (West Germany) was ushered in by the educational radio broadcasts around the end of the 1960s. Aside from the formation of the FernUniversität (Open University) in West Germany in 1975, there were significant developments in distance education occurring at the major universities in the German Democratic Republic (East Germany). After German reunification in 1990, the new unitary state launched programs to advance the development of distance education programs at conventional universities. Germany's campus-based universities (Präsenzuniversitäten) created various entities, including central units and consortia of universities to design and market distance education programs. Hybridisation provides the necessary prerequisites for dual mode delivery, such as basic and continuing education programs, as well as for the combination of distance and campus-based education (Präsenzstudium). Hybridisation also has also opened the door for the creation of new programs.

Following an initial phase in which distance education research is expected to centralize a trend towards decentralisation is likely to follow. The German Association for Distance Education (AG-F) offers a viable research network in distance education. Two dual mode case studies are also be surveyed: The Master of Arts degree, offered by the University of KoblenzLandau, with Library Science as the second major, and the University of Kaiserslautern, where basic education will continue to be captured within the domain of the Präsenzstudium or campus-based education.

The area in which distance education is flourishing most is within the field of academic continuing education, where external experts and authors are broadening the horizon of the campus. Multimedia networks will comprise the third generation of distance education.
\end{abstract}




\section{Overview of the German Educational System}

Germany's educational system has experienced a series of transformations during the last 40 years. Similar to trends occurring in other countries, there has been a marked increase in student enrolment and in response to growing demand, admission requirements have been relaxed considerably and new universities have been established. After a period of expansion, transformations are now taking place. Schools providing basic education are being given a greater degree of autonomy, and universities are being granted a higher degree of responsibility in the management of their own budgetary affairs. These trends reflect increasing deregulation of the part of the unitary state (federal government), which is incrementally withdrawing from educational matters.

In Germany, formal schooling takes 13 years and concludes with what is known as the Abitur or final examination that qualifies students for admission into a university. Students with 12 years of formal schooling who meet the entrance requirements called Fachhochschulreife are allowed into an applied science university.

A course of study at a German university generally takes five years (ten semesters) and is completed with a diploma, a state examination, or a Master of Arts degree. The ten-semester period of study is also one of the formal requirements for doctorate programs. The right of conferring a Doctorate is exclusively reserved for the academic universities, whereas Germany's applied science universities do not confer this degree.

Education offered by publicly funded institutions, including continuing education, is the responsibility of the unitary state - but only for state owned facilities. Private institutions, professional associations, and semi-governmental institutions, however, control the majority of Germany's continuing education market. On the job training programs play a significant role in the private sector, enabling the qualification and advancement of their employees. Education, therefore, is also a concern of the country's 16 federal states.

In contrast to its unitary state, the states have been granted "independence in cultural and educational matters," which confers them the right to make their own decisions regarding educational matters within their respective political boundaries. The organisation of the German educational system, therefore, is not centralized, but multi-centralized. Each of the 16 federal states operates its own Ministry of Education, Art and Culture, making them responsible for their own educational system, and consequently their own fiscal affairs through corresponding administrative regulations. ${ }^{1}$

In Germany, school and university education is free, in that no school or tuition fees are charged. Children from low-income families may apply for educational grants to finance their education, a fact that reflects the socialist principal that

International Review of Research in Open and Distance Learning 
no one should be prevented from studying due to financial constraints. Thus, equal opportunities exist for students from both high- and low-income families. However, the above mentioned educational grants are not funded by the unitary government, they are funded by the 16 federal states. As a result, a significant portion of the responsibility for the country's educational system is shared by the 16 federal states alongside its unitary state.

In contrast to basic education programs, the unitary state assumes direct responsibility for vocational training programs delivered in accordance with various agreements made with industrial sectors and other special interest groups. As a consequence, these agreements exert an indirect influence on the educational system of Germany's 16 federal states, as formally articulated in the Service and Salary Classification Act, legislation that applies to the entire civil service sector and to all schools and universities. The unitary state also exerts its influence in other areas, such as through a research promotion program and supportive legislation that applies specifically to universities throughout the Federal Republic. The unitary state also helps fund the construction of new universities, but under the supervision of the respective 16 federal states.

The "General State Law of the Prussian State" (1794) described universities as "organisations of the state." This law also granted the universities "the right to a privileged coordination in accordance with the legislation," a principle that has survived to this day. The constitution of the Federal Republic of Germany also guarantees the "freedom of research and teaching," granting university professors the right to individually determine the content and form of their research and teaching. Responsibility for promotion of academic talents through the internal process of conferring a doctorate and postdoctoral lecturer qualification (habilitation) also falls under the scope of university autonomy. ${ }^{2}$ Since all universities in Germany are combined research and teaching institutions, no formal institutional divisions exist.

Recent developments indicate far reaching changes are underway in Germany's higher education system that will reshape the nation's future. Recently, Germany's universities and applied science universities were authorized to award Master's and Bachelor's degrees, which could subsequently lead to the replacement of the current German diploma. In some federal states, the duration of study in the school sector has been reduced from 13 to 12 years. Greater autonomy has likewise been granted to universities with respect to the allocation of state funding for the fulfilment of their duties. Overall, the general impression is that Germany's educational system is adjusting to international competition and market dictates and as a result, is loosing some of its unique qualities.

International Review of Research in Open and Distance Learning 


\section{History of Distance Education at German Uni- versities}

\section{Educational Radio Broadcasts}

The birth of academic distance education in the Federal Republic of Germany took place during the latter half of the 1960s when people began to speak of insufficient numbers of higher education graduates in the German population. In response, educational radio broadcasts were initiated in 1966 by the Hessian Broadcasting Corporation (Hessischer Rundfunk) and the University of Frankfurt, with the assistance of representatives from broadcasting corporations, other universities, ministries of education, art and culture, and the newly established German Institute for Distance Education (Deutsche Institut für Fernstudien or DIFF) at the University of Tübingen. Thus, a new distance education system was developed that reached thousands of people each year via a multimedia system of radio broadcasts, support groups, and eventually television (Begleitzirkel).

Since the first educational radio program was broadcast: "Towards and Understanding of Modern Society (Zum Verständnis der modernen Gesellschaft)," hundreds of thousands have participated in this form of academic programming, which has both evolved with time and helped a large number of students acquired certificates via distance education (Greven, 1998). However, 32 years later, most broadcasting companies were no longer willing to broadcast educational content (Kapple, 1997) and as a result, Germany's educational radio broadcasts were discontinued after 1998.

\section{FernUniversität (Open University)}

The 1970s witnessed the teaming up of nearly 80 German universities to form the University Association for Distance Education in Multimedia (Hochschulvereinigung für das Fernstudium im Medienverbund or HVF). Subsequently, collaborative distance education projects were launched and material developed. However, in the absence of a cohesive infrastructure, the country's varied distance education approaches were temporarily brought to a standstill. Confronted with this situation, in December 1974, the state of North Rhine-Westphalia decided to consolidate their distance education activities through the establishment of the FernUniversität (Open University) in Hagen, a higher education institution patterned after Britain's Open University, established five years earlier. Despite political objections, the development of the FernUniversität continued apace, primarily because it was the first and only institution to offer flexible basic university degree programs designed to address the needs of working adults and of those who for reasons of geographical or temporal constraints would not

International Review of Research in Open and Distance Learning 
be able to access higher education. To this day, the FernUniversität retains a dominant position among Germany's distance education providers. It also plays a significant role in the Association of European Open Universities (Vereinigung europäischer Fernuniversitäten), established a few years ago.

Nonetheless, academic continuing education via distance education modes did not come to the fore until recently. But thanks to the 1992 recommendations of the scientific and technical advisory committee (Wissenschaftsrat, 1992), and the growing use of multimedia, distance education is now gaining recognition.

\section{Other Approaches}

While the FernUniversität officially started operations in autumn 1975, another distance education project was developing parallel to this advancement. The 16 federal states, with their cultural and educational autonomy, collectively agreed to conduct an "experiment in distance education using multimedia systems" (Versuch für das Fernstudium im Medienverbund). Referred to as the FIM state experiment, distance education materials were developed for the initial study phase in some subjects, and subsequently resulted in increased university enrolments. However, because the corresponding departments at the universities only participated peripherally, the experiment subsequently met with failure. Indeed, from the outset the FIM state experiment was not intended to be anything more than a relief measure for overcrowded universities. However, after the experiment concluded in 1981, projects, pilot experiments, and finally standardized course offerings were in place and materials for university continuing education programs had been prepared and utilised within the scope of such projects, pilot experiments, and standardized course offerings.

In the 1980s, another distance education option developed from the field of private distance education. The commercial provider, AKAD, established three distance education colleges (Rendsburg, Lahr and Leipzig) that were awarded official recognition by their respective federal states. In some cases, and without any prior formal qualifications for university admission, students attending these institutions could earn a diploma $(\mathrm{FH})$ in the field of economics. Recently, AKAD founded an academic college for continuing education in BadenWürttemberg. The 1980s also saw the establishment of distance education colleges operated by private sector institutions, including the Study Association Darmstadt (Studiengemeinschaft Darmstadt).

\section{Distance Education in the German Democratic Republic}

Prior to the reunification with the Federal Republic of Germany in October 1990s, the former German Democratic Republic (GDR) enjoyed a fully devel-

oped distance education system in which most universities had participated

International Review of Research in Open and Distance Learning 
since the 1950s. The primary purpose of this system was post qualification of management personnel who had been designated by the then ruling Socialist Unity Party (SED) for professional posts that, under most circumstances, would normally require a university degree. Therefore, personnel who held such professional positions without any corresponding university education were required to engage in and complete a post qualification course of study. Accordingly, "members of the cadre" were "dispatched" to distance education programs to these correct labour-planning errors. According to the 1992 recommendations of the scientific and technical advisory committee, the GDR system functioned as a degree oriented, academic continuing education system that, in turn, helped reduce campus attendance periods. In 1988, there were approximately 100 basic distance education study courses at 31 universities. In addition, there was also a larger number of continuing education and postgraduate study courses avail-

able. Some universities handled large student quotas, with two thirds of the total number of distance education students enrolled at five universities. The TU (Technical University) Dresden, for example, served approximately 37,000 distance education students, and graduated 20,000 students during a 40-year period. The principal subjects or majors offered were in technical disciplines, business, economics, historical philosophy, and law.

Nonetheless, because this system was based on a sizable proportion of campus attendance owing to the "delegation principle," after the reunification of the German people in 1990, it soon became clear that no commercially operated enterprise could in the long run afford to grant leave to its employees for extended periods of up to 50 days to participate in distance education courses. In the previous GDR system, such a release would have included both practical training and access to corresponding technical equipment that provided an optimal balance of theoretical education and practical application. This didactic combination is one reason why many former participants miss the old GDR distance education system. However, the fact remains that course contents were often deficient or ideologized in several subjects, e.g., economics, law, philosophy and history. Despite Germany's trend towards deregulation since the 1970s, such an educational planning instrument of a state controlled economy could not last in a free economic system. Today, only rudiments of the GDR distance education system have survived, primarily in disciplines like medicine and nursing.

\section{Three New Impulses}

Distance education in the Federal Republic of Germany entered a new phase in the 1990s, as evidenced by three developments: first, the university programs of the Federal Government with their distance education components; second, the international - in particular the European - situation; and third, the recommendations of the scientific and technical advisory committee. These three developments contributed to the following four developments: (1) In addition 
to the large centralized system of the FernUniversität, individual universities became the focus of attention; (2) distance education courses were established nationwide on a decentralised basis; (3) networks of university facilities and programs emerged; and (4) amidst the variety of new flexible courses offered, academic continuing education emerged at the forefront.

New communication media, and in particular personal computer and network technology, provided an additional boost to distance education. As early as 1995, multimedia was already a catch phrase. With the dawn of the 21 st century the full dimensions of the Internet and the resulting possibilities for systematic learning and study processes are becoming even more evident. Distance education has again received new impetus thanks to technological developments, and traditional educational institutions are now finding themselves compelled to develop new technical communication forms, even if they lack the necessary didactic preparation. And although merely making educational materials available on the network does not necessarily involve distance education, Internet supported distance education courses are mushrooming. New facilities for telelearning are being established, Internet universities are being launched, and "virtual universities" are establishing themselves as projects of university associations (Kapple, 1996, 1999).

Today, one would define distance education not as a course of study that overcomes the geographic distance between teacher and learner, but rather one that supports the self-determination of the learner. In this respect, learner selfdetermination may pertain to three levels: content, time and location. Distance education provides learners with the greatest possible degree of flexibility and independence with respect to preferred course content, time, and location.

\section{Current situation}

Germany has a distinctive and well-developed distance education system. In the year 2001, 133 distance education courses were offered at 27 state owned campus-based universities (Präsenz-Universitäten) (Hochschulrektornkonferenz, n.d., http://www.hrk.de), with an approximate total enrolment of 20,000 students. Sixteen of these study courses are at the basic level - i.e., for the Abitur or university entrance examinations - and lead to a first academic degree conferring professional qualification. One hundred and seventeen continuing education courses are also being offered and linked to a specific course of study that combines several years of working experience. In total, 37 per cent of all students enrolled in Germany's universities earn their academic degree in this fashion. The remaining continuing education courses are certificate programs, lasting only one or two semesters.

A variety of university structures are involved in the delivery of distance educa-

International Review of Research in Open and Distance Learning 
tion courses. Learning centres comprise either science centres or service units. Science centres are regarded as superior to service units, because they engage in research and teaching and hence, are taken seriously as part of the academic establishment. Besides learning centres, there are a number of consortia operating in Germany: namely three distance education course associations, and five virtual universities sponsored by various collaborating universities and which offer distance education courses under the auspices of continuing education. Most members of the consortia have been granted university status. The consortium structure allows for formation of a central office that acts as a cohesive coordination unit. While consortium members identify and develop the content, types of courses offered, and supporting policies, the central office implements decisions within the structures of the individual universities. Thus, the central office concentrates on delivery and staffing of the continuing education courses delivered via distance education in accordance to specific requirements.

In Germany, basic education courses are provided gratis by the state; students do not incur any costs from the time of course commencement to the attainment of a first profession qualifying degree at a campus-based university (Präsenzhochschule). However, universities are allowed to charge fees for costs incurred in the production and distribution of course materials. No costs are charged for tutoring and other academic activities.

The German Higher Education Framework Law (Deutsche Hochschulrahmengesetz) and the University Laws of the Federal States (Universitätsgesetze der Länder) have different rules with respect to continuing education and as such, courses financed by student fees must be marketed through the corresponding participating institutions.

At campus-based universities (Präsenzuniversitäten) that offer distance education courses, the question arises as to what extent dual mode is possible. The dual form of the dual mode system is presented below.

\section{Basic Education and Continuing Education:}

Of the 133 distance education courses currently offered, only six are basic and continuing education courses. Significantly more distance education course offerings are available through private universities, primarily because private universities can charge participation fees. This is where a fundamental problem arises. Basic study courses offered by state institutions are provided free of charge, yet according to law, participation fees may be charged if a student wishes to enrol in the same course via a continuing education programme. In this case, legal discrepancies cannot be avoided. The easiest procedure to follow, therefore, is to divide participants in terms of time and space. No judgement shall be passed at this point regarding the pedagogic usefulness of an identical offer for first time and/or adult students. More frequently (but statistically not

International Review of Research in Open and Distance Learning 
recorded) is the use of supplementary and substitution course and lecture materials used within the framework of basic education. In this case, clear provisions regarding costs and integrity of the course offerings must be central.

\section{Distance education and campus-based education (Präsenzstudium):}

Simultaneous course offerings using both a distance education and campusbased delivery (Präsenzstudium), is another option. Dual forms of study are growing in popularity, especially in North America. However, dual offerings are not as effective in Germany, simply because geographic distances are seldom an issue. As well, overall content would have to be organised to complement the dual modes. The dual mode component utilises available resources from both campus-based and distance education programs in the development of courses that encompass both study forms and in which distinctions in terms of content are clearly effected where possible. Such an example is Germany's Master of Arts Degree in Library and Information Science (Magisterstudium Bibliotheks - und Informationswissenschaft).

Research topics in distance education include planning, organisation and implementation of courses, didactic and methodical problems relating to distance education and, of course, the use of new media. To date research in distance education has been conducted by the German Institute for Distance Education Research at the University of Tübingen (Deutsches Institut für Fernstudienforschung or DIFF). Whereas, the Central Institute for Distance Education Research at the FernUniversität in Hagen, (Zentrales Institut für Fernstudienforschung or ZIFF) concerns itself with fundamental principles and application research in distance education. In the case of decentralisation of distance education research, an increasing number of central distance education facilities of campus-based universities (Zentrale Einrichtungen für Fernstudien der PräsenzUniversitäten) are also engaged in distance education research.

Formulation of research topics, avoidance of duplication, and discussion of major research points and their respective results, require an ever-increasing degree of coordination. This level of coordination can only be achieved by dividing up the work involved. On the one hand, some coordination is performed by the unitary states. One is the Federal States Commission for Educational Planning and Research Promotion, an organisation in which the Federal Government and the Federal States work together on projects such as financing new developments in the field of distance education. Up to now, however, corresponding coordination was also carried out by the DIFF, which devoted its attentions to the academic support of these new developments. On the other hand, the Association for Distance Education at Universities (Arbeitsgemeinschaft für Fernstudium an Hochschulen) exists as part of the Association for Adult University Education (AUE). As a result, Germany's universities are furnished with a strong platform for the formulation of ideas and the practical realisation of goals pertaining to

International Review of Research in Open and Distance Learning 
distance education.

\section{Best Practice, Local Reports}

\section{University of Koblenz-Landau, Centre for Distance and Continuing Education}

The Centre for Distance Education and University Continuing Education at the University of Koblenz-Landau is engaged in the practical side of development, planning, implementation of distance education and related research activities. At present, the Centre offers three distance education study courses within its academic stream, and more than 10 one-semester university continuing education courses in the distance education program. Current student enrolment in all programs stands at 450 .

One illustrative program is the partial Master of Arts degree (Magisterteilstudiengang) in Library and Information Science. In contrast to Master of Arts degrees offered in English-speaking countries, this Master of Arts degree (M.A. Magister Artis), can be completed by studying either two major subjects or one major with two minor subjects. The duration of study is 2,700 hours spread over nine semesters, and includes an M.A. thesis in the first major subject. Faced with few restrictions, students are given a choice of subjects. Regulations permit the study of subjects not offered at the university itself. Since 1999, students enrolled at the University Koblenz-Landau can also enrol, as part of a second major, in subjects taught as part of the Library and Information Science major for the M.A. at Humboldt University in Berlin. Because both universities have a contractual arrangement and the support of the Federal and Rhineland Palatinate State Governments, Koblenz and Landau students may study this particular subject without any change of location. However, the criterion of self-determination of content, time and location that applies in this case, is a significant exception to the general pattern of distance education in Germany.

Study materials developed at Berlin University are divided into modules. Course materials developed for each module consists of published literature, study manuals, and an accompanying student guidebook that provides methodical suggestions, gives didactic instruction in the selection of advanced literature, and contains questions for oral and written exams. Regular videoconferences provide students at both the Koblenz and Landau locations (200 km apart) the opportunity to have personal contact with their Berlin based lecturers located more than $600 \mathrm{~km}$ away. Seminars, exercises, consultations and even examinations are conducted via videoconferencing.

To avoid lapses in concentration and overall fatigue, videoconference sessions do not exceed two hours. All three locations can be linked up simultaneously.

International Review of Research in Open and Distance Learning 
The rooms are furnished with the appropriate technical equipment and personnel. Telephone lines with six ISDN-interfaces using conventional television engineering and the corresponding Codecs ensure high quality audio and video transmission. Each studio requires a control unit that technically regulates the elements of video conferencing as well as enables the display of corresponding text or graphic pages via the Internet. An additional telephone connection is also available in the event that problems occur at any of the locations. The overall technical and methodical control of the event is the responsibility of a coordinator, thereby relieving students and lecturers of any technical work involved. To enhance participation, the number of participants for each session is limited to 15; the optimal number of participants is less than ten. Difficulties encountered during videoconferencing must be overcome by students on an individual basis; however, all participants soon develop competency in videoconferencing, as reflected in disciplined behaviour such as dialogue, preparation, timely processing of problems, etc.

In preparation for videoconference sessions, students have the use of a computer that allows them to download and read the student guidebook, submit questions to course lecturers prior to the videoconference, and work on assignments that are sent and submitted via email. Course specific newsgroups moderated by lecturers serve as discussion forums that cover topics in detail. A newsgroup provides administrative information and communication. Students are provided with extensive listings of compulsory online course readings, and links to advanced literature. Searchable resources from all major European libraries and corresponding order lists are also available to students, along with the option of electronic enrolment, access to curricula, important dates, addresses, and contact lists. It goes without saying, all study related Internet pages as well as downloadable material, newsgroups, and other information channels, are password protected. In order to form electronic media competencies from the start, a first term IT course acquaints students with the basics of Hypertext Mark-up Language (HTML) so that they can design and program their own homepage. Once a year, students and lecturers meet on a voluntary basis to exchange ideas. This meeting, held for one week, is often combined with field trips.

As of Autumn 2001, the fourth group was enrolled in the Master's degree program. In the first three groups, 40 students were studying their second major subject, Library and Information Science. Initial evaluations show that students readily accept of this form of study. Students rate highly the diversity of learning produced by the versatility of their activities. Students also report that they received more support and assistance than they would otherwise in traditional campus-based situations (Präsenzstudium). They also report a stronger affinity with their lecturers with the Centre for Distance Education than they would in campus-based situations. As reflected by increased levels of learning success, student willingness to achieve is enhanced as a result of the required study discipline and related videoconference sessions. 
Lecturers also positively rate this method of distance education delivery, despite the necessity of intensive preparations for their lectures and video appearances. Indeed, they have to convince themselves of the transmission quality of their courses, plus they also are required to carry out trial link-ups. They also report their concentration levels must be considerably higher than they otherwise would be conducting campus-based teaching sessions (Präsenzveranstaltung). Nonetheless, lecturers also develop a higher level of identification with their distance education students, such as knowing their names, along with their work habits and capabilities, much sooner.

The hybrid form of distance education described above, including its multimedia components, is certainly not an exception in Germany's distance education sector. However, in spite of its success, it is still a minority element. However, recognising its intrinsic value, considerable attention is now being paid to the research and development of new distance education delivery modes like the one described above. For example, a thorough analysis of previous experiences and outcomes led researchers to the realisation that producing a mere carbon copy of Web-based academic lectures contained in Germany's so called tele-teaching program would only produce disadvantages. On the other hand, face-to-face conferencing, a situation where students have the opportunity to ask their lecturers questions and receive answers directly, would yield tremendous value. In sum, it was recognized that the main value of videoconferencing rests more on its seminar like exchanges and its methodical exercises, than on its formal lecture components. Within this mix, corresponding course materials are made available to students on the Internet and in printed form. This study form described above is suitable for basic and continuing education programs.

\section{University of Kaiserslautern, Centre for Distance and Con- tinuing Education (ZFUW)}

At ten years old, ZFUW is a mere youngster among the continuing education institutions, many of which were already established in Germany's universities by the end of the 1970s. Bearing the same name as its sister institution in Koblenz, ZFUW has become a leading provider of postgraduate distance education courses. More than 1,500 students throughout Germany and abroad are currently enrolled in programs such as: Human Resources, Medicine, Natural Science, Technology, and Management.

The role of ZFUW has enabled the University of Kaiserslautern to become a dual mode university. Prior to the development of ZFUW, the only continuing education courses offered at the university were campus-based courses in the area of basic education. The establishment ZFUW, however, resulted in a fundamental change. Today, the university is already perceived as the Open University Kaiserslautern. The integration of the distance education unit into the university corresponds more or less to the Keegan model shown in Figure 1

International Review of Research in Open and Distance Learning 
below.

Fig.1: Distance education courses from a university model

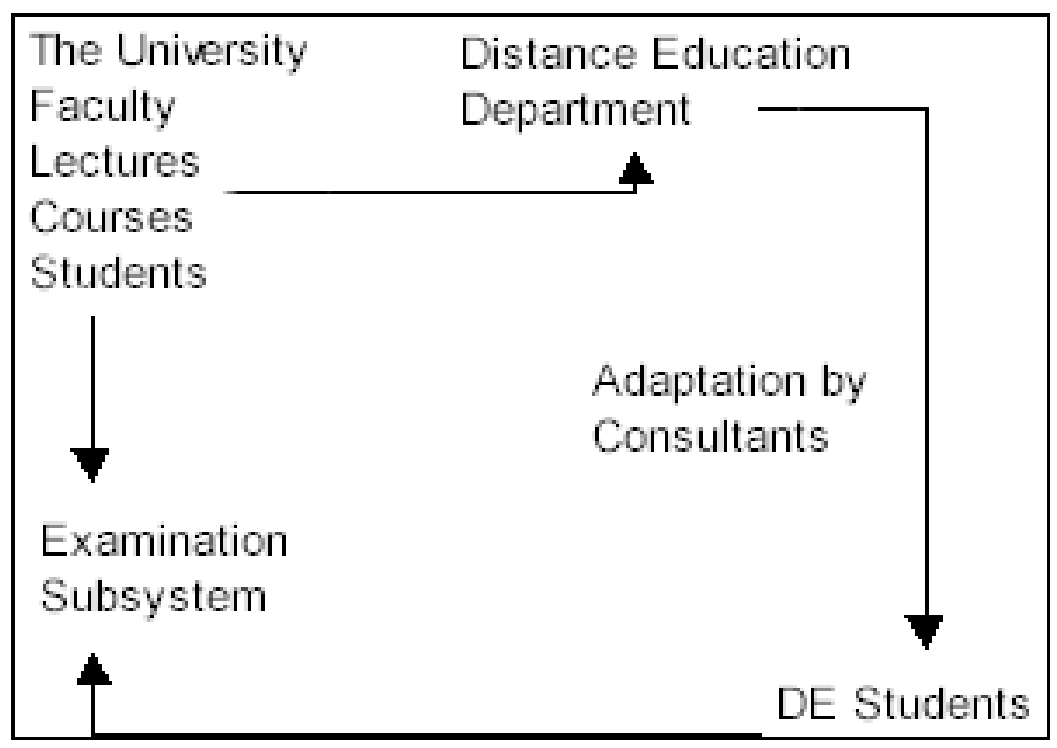

The decision to offer academic continuing education via distance education namely all its educational contents with an exclusive connection to current topics within the framework of teaching and research - is in line with the view that distance education is a separate teaching and instructional organisation form (Peters, 1997) that can develop its full effectiveness when it is used for continuing education purposes. Recognising that attempts to utilise distance education for basic education are more likely to fail, as shown by a large number of experiences gathered in this respect, ZUFW decided not to offer basic education via distance education, the reason being that in basic education it is essential to establish learning experiences and strategies that often cannot easily be communicated in the distance education mode, if at all. On the other hand, university graduates often possess the intellectual qualifications and learning strategies necessary to acquire the knowledge essential to the preservation of their existing jobs or for the advancement their professional careers in a systematic and goal oriented manner. They have learned how to learn, are able to distinguish the essential from the nonessential, and to discern the relevance of the educational contents with regard to their respective goals. An academic beginner is hardly in a position to achieve the same results. This view is confirmed by the fact that approximately 80 per cent of the participants of the ZFUW acquire a degree, while the international success rate in the basic distance education sector is only about 20 per cent.

International Review of Research in Open and Distance Learning 
ZUFW is an integral part of the university. In the development and conceptualisation of a program, ZUFW always strives to ensure that the know-how developed in the faculties flows into the university's continuing education activities. Therefore, a faculty or a faculty representative assumes responsibility for each continuing education program offered by ZUFW in the field of continuing education.

Despite the intensive efforts towards anchoring the programs and structures within the core sectors and competencies of the university, it turns out that continuing education is developing a remarkable momentum of its own accord. For instance, because the University of Kaiserslautern is best known for its focus on engineering and natural sciences, one would naturally expect to find its postgraduate continuing education programming focused on these sectors. In reality, however, the university's most successful programs are found in the field of Human Resource Management - a so called soft skill sector - and therefore a thematic area which does not belong to the university's core sectors, but instead to its marginal sectors. Under normal circumstances, a university would hardly be in a position to develop and deliver programs outside its core specialities. This fact alone demonstrates the strength of the continuing education/distance education system, a tactic that permits the integration of external experts into the expanded profile of the university's core sectors, thus providing the university with an enhanced image that it would not otherwise be able to achieve without its distance education components. In sum, continuing education delivered via distance education not only contributes to the satisfaction of educational needs, it also constitutes an opportunity for an offering university to develop and expand its role and profile in sub-sectors in which it was only marginally or previously not active.

The basic concept of the continuing education/distance education program at the University of Kaiserslautern has been tried and tested. The duration of all programs of study connected to its graded university certificate (one that will in the near future lead to a Master's degree) is equivalent to two or four semesters. The foundation of its studies is formed by what are known as study letters, i.e., textual materials prepared according to the principles of distance education didactics and that are suitable for self-study.

In contrast to the distance education systems developed by the British Open University that uses books in combination with study guides, ZFUW's entire range of educational materials is produced especially for the teaching purposes of individual course authors. The material production also differs from other systems. For example, at the British Open University, educational materials are developed by author teams, and individual authors are subordinate to the complete work. Each educational text produced in the University of Kaiserslautern, however, intentionally bears the individual trademark and influence of its author. This fact reflects ZFUW's conviction that academic instruction is made up of individual interpretations, even in areas where an "established 
school of thought" has gained acceptance. Thus, it is made clear to students from the start that they are not dealing with an objective scientific "truth," but with an interpretation that is still evolving.

The didactic concept pursued by the facility is that of "guided self-study." Educational materials are produced for independent work, yet they are also accompanied by learning goals, instructions and exercises to be completed within predefined deadlines. In this respect, a fully self-controlled learning process as described and demanded, in part, in social science literature (Knowles, 1975), does not take place, nor is it aimed for. The student support system technically embraces all options currently offered by communication technologies such as: telephone, fax, email, and bulletin boards that are in some cases moderated, and in other cases not.

Students registered in ZFUW 's distance education programs participate in compulsory attendance activities (Präsenzphasen), which usually take place on a weekend at the conclusion of each semester at the university. These meetings serve to reinforce understanding of the subject matter through seminars, practical training, laboratory work, and written assignments. Compulsory attendance also distinguishes it from other established distance education systems, where participation at campus-based events (Präsenzveranstaltungen) is often purely voluntary. The combination practiced at the University of Kaiserslautern, comprised on a guided self-study phase with a mandatory face-to-face activity (Präsenzpflicht), is based on the conviction that face-to-face encounters are an integral part of teaching and learning, and should not be left to the discretion of the individual participants. In short, attendance fulfils a pedagogic purpose.

In the past, ZFUW chose not to produce its own instructional media such as videos, audiocassettes or CD-ROMs, nor will it will do so in the future. In essence, this leaves out one step in the distance education development phase as conceptualised by Garrison (1989). At present, ZFUW is putting a great deal of effort and commitment into transforming the text-based versions of its programs of study to an online supported study format. A pioneer of this trend is ZFUW's "Personnel Development" study course, where a large number of modules can be studied in the traditional form or alternatively, in the electronic form. The key philosophy, in which the transformation of distance education in the University of Kaiserslautern reflects a "technology based distributed learning" approach, is followed by a large number of American universities. The Institute for Academic Technology, University at North Carolina, offers this description of the aforementioned "technology based distributed learning" approach:

A distributed learning environment is a learner-centered approach to education, which integrates a number of technologies to enable opportunities for activities and interaction in both asynchronous and real-time modes. The model is based on blending a choice of ap- 
propriate technologies with aspects of campus-based delivery, open learning systems and distance education. The approach gives instructors flexibility to customize learning environments to meet the needs of diverse student populations, while providing both high quality and cost effective learning (1995).

The act of transformation is accompanied by the initiation of new continuing education programs, which will emerge as Internet supported continuing education courses without any preceding print version. The e-Learning concept developed by ZFUW, therefore, is a model that extends to the faculties of the university by which it is then adapted. Viewed from this perspective, ZFUW has evolved into a media competency centre representing the new forms of teaching and learning, both within and outside the university.

\section{Distance Education in a Digital Age}

Multimedia networks are the third generation of distance education, a theory that was advanced by Garrison (1989). At that time, the claim was more of a prophecy than a distance education reality. Even in the international context i.e., in England, the U.S. and in other parts of the world - the fact that distance education would have already reached the digital age was hardly considered a possibility. Aside from some ambitious e-Learning initiatives, there were only a few experiences which could be presented and which could have corresponded with the theory forwarded by Garrison. Today, the situation is fundamentally different. E-Learning is a mega-trend, and it is presenting a challenge for all educational facilities to keep abreast of the changes triggered by the electronic media.

As is true on the international level, the trend in the Federal Republic of Germany is towards the adoption of what Mitra (1999) refers to as "complete or complementary or supplementary environments on the one hand, and on the other, the virtual instruction facility" (Mitra, p. 121). Complete Environments come into being in the newly established virtual universities or virtual campuses, most of which resulted from the linking up of various universities. In a way, they can be regarded as a new type of university that supplements the already established forms of campus-based (Präsenz) or distance education facilities. Complementary or supporting or supplementary environments refer to face-toface instruction enriched by online technologies, a trend that is emerging both in open universities and in campus-based universities (Präsenzhochschulen). In other words, both types of university are acquiring online components, digitalizing individual courses offerings, and adding additional features and resources via the online mode, to existing course offerings. Meanwhile, distance education programs at campus-based universities (Präsenzhochschulen) are following the same line of action. They are following the same process or logic as their core

International Review of Research in Open and Distance Learning 
facilities or role models - namely the open universities. For example, university centres in Oldenburg, Lüneburg, Hildesheim, Kaiserslautern, Koblenz, and even Karlsruhe are offering online instructional support programs in the same manner as the state owned distance education colleges.

The results produce a relatively broad range of variants. The offerings of individual facilities include Web-based training as well as the organisation of online seminars or the option of downloading educational materials. Progress has also been made with respect to internationalization as demonstrated by examples such as the "Master in Distance Education" at the Oldenburg University, or to use another example, the cooperation between the ZFUW at the University of Kaiserslautern and the University of British Columbia in Canada.

On the whole, the rate of development is slower than was anticipated by many diagnosticians of future learning environments. The main reason is that that many universities - and this also applies to distance education providers - are currently dealing with the problem of appropriate technology as it affects production of content. Resistance on the part of German university professors, such as those sometimes observed in the U.S.A. regarding the introduction of e-Learning (Ceraulo, 2002) has not materialized. Nor are there any signs that such opposition might be expressed in the future. However, there are acceptance problems on the part of both of academics and students. For example, FernUniversität, which recorded a current enrolment figure of approximately 54,000 students, reported that 16,000 students have applied for Internet access and around 200 students are using the online programs. This is a clear indication that at present, e-Learning in the academic sector is more likely to be a risky undertaking with an uncertain outcome, primarily because acceptance and interest among participants may only be of a limited nature, although this situation might possibly change in the future.

Distance education programs currently operating signal a good starting position at the onset of the digital age (Schulmeister, 2001). Open universities and dual mode structures retain copyright of the educational materials that entitles them to digitally reproduce and distribute these contents and to transform them into multimedia learning environments. Nonetheless, involvement in online instruction - and this is overlooked at times - can monopolize resources that are urgently needed for updating existing materials that, in all probability, will be the information, teaching and learning content carriers for quite some time.

In the long run, a new problem will arise for dual mode structures. Whereas, in the past, these structures were able to legitimise their right to exist by pointing to the fact that distance education is a sui generis instructional form, requiring specialized personnel and specific measures, this legitimisation will become invalidated with the gradual expansion of e-Learning within conventional higher education institutions. If a faculty starts to operate successful e-Learning operations without reference to the existing distance education unit, then distance education units may have to justify their right to continue. The chances of 
survival and coexistence of the distance education facilities with dual mode programs will be decisively dependent on whether they find a rational argument for this purpose. One possible solution may be for distance education facilities to form media competency centres that involve computer departments, faculties, and media designers. Distance education of the future - and there is no doubt about it - will either be digital or it will cease to exist. 


\section{References}

Arbeitsgruppe Bildungsbericht am Max-Planck-Institut für Bildungsforschung (1994). Das Bildungswesen in der Bundesrepublik Deutschland. Strukturen und Entwicklunge im \&\#220berblick. Reinbeck bei Hamburg.

Arthur Andersen (2001): Studie zum europäischen und internationalen Weiterbildungsmarkt, Bundesministerium für Bildung und Forschung (BMBF)

Bundesgesetzblatt Jhg. (1999). Section I No.3, Bonn 27.1.

Deutscher Bildungsrat (1970). pg. 197

Ceralo S. (2002). Change comes hard: PhD. Higher Education's View of Online Learning follows the familiar "PC Pattern" [Online] Available at: http://www.elearnmag.org/index.cfm.

Fernstudienprogramme der AG-F Mitglieder, Sonderheft 2000 AUE Hochschule und Weiterbildung, Regensburg Dezember, 2000.

Garrison, D.R., (1989). Understanding Distance Education: A Framework for the Future. Boston: Routledge.

Graessner, G. (1996). \&\#220berregionale und regionale Kooperationsbeziehungen im Feld der Erwachsenen- und Weiterbildung; In: Der AUE an der Schnittstelle zwischen tertiärem und quartärem Bildungsbereich - Bilanz und Perspektive, Festschrift aus Anla\&\#223 des 25jährigen Bestehens des AUE, AUE e.V. Bielefeld

Greven, J. (Hrsg. 1998). Das Funkkolleg 1966-1998. Ein Modell wissenschaftlicher Weiterbildung im Medienverbund. Erfahrungen - Auswertungen - Dokumentation, Weinheim

Hochschulrektorenkonferenz [Online] Available at: http://www.hrk.de.

Institute for Academic Technology, University of North Carolina, March, 1995. In: Centre for Educational Technology Steering Committee. A Vision Statement for Distributed Learning at the University of British Columbia. September 23, 1996. [Online] Available at: http://www.cet.ubc.ca/about/vision.html.

Kappel, H.H. (1996). Fernstudium als flexible Weiterbildung. Wissenschaftliche Weiterbildung gewinnt neue Dimensionen, in: Dikau, J., Nerlich, B., Schäfer E. (Hrsg. 1996): Der AUE an der Schnittstelle zwischen tertiärem und quartärem Bildungsbereich - Bilanz und Perspektive. Festschrift aus Anla\&\#223 des 25jährigen Bestehens des AUE, Bielefeld, S. 168 - 184

Kappel, H.H. (1997). Das Ende des Funkkollegs. Von den Schwierigkeiten einer Bilanz nach 30 Jahren Medienverbund, in: AUE Hochschule und Weiterbil-

International Review of Research in Open and Distance Learning 
dung Informationsdienst 1/1997, S. $3-7$

Kappel, H.H. (1999). Qualifikation und Erfolg. Ein praktischer Führer für Ihre Karriere mit Zukunft, 3. Aufl. Frankfurt am Main

Keegan, D. (2001). Distance Training. Taking stock at a time of change. London, New York: Routledge.

Knowles, M. S. (1975). Self directed learning: A Guide for Learners and Teachers. New York: Association Press.

Kommer, A.; Grae\&\#223ner,G.; Prokop,E. (1997). University Continuing Education in Germany, Beitrag zur THEG3 THENUCE. [Online] Available at: http://www.aww.uni-hamburg.de/html/aue/german-UceOrg.html.

Lehmann, B.; Loeper, J. (1997). Implementation von Fernstudienangeboten an Präsenzhochschulen; Vortrag auf der Jahrestagung der AG-F des AUE in Kaiserslautern

Mitchell, V.A. (2000). Universitäre Weiterbildung in Europa, Ein Handbuch für Führungskräfte, THENUCE-DIS, European SOCRATES Programme, EUCEN Liège

Mitra, S. (1999). Virtual Institutions in the Indian Subcontinent (Including Bangladesh, Bhutan, India, Nepal, Pakistan, and Sri Lanka). In: Farrell, G.M. (ed): The Development of Virtual Education: A Global Perspective. A Study of Current Trends in the Virtual Delivery of Education. The Commonwealth of Learning: Vancouver, Canada. 125-134.

Peters, O. (1997). Didaktik des Fernstudiums. Berlin.

Rahmenvorgaben für die Einführung von Leistungspunktsystemen und die Modularisierung von Studiengängen; Beschlu\&\#223 der KMK vom 15.9.2000

Schulmeister, R. (2001). Virtuelle Universität, Virtuelles Lernen. München, Wien

Weber, K. (1995). Profil und Qualität der wissenschaftlichen Weiterbildung; Beiträge zur Hochschulforschung 4-95, Bayerisches Institut für Hochschulforschung und Hochschulplanung

Wissenschaftsrat (1992). Empfehlungen zum Fernstudium, Hannover

Universitätsgesetz vom 23.5. (1995). Ministerium für Bildung, Wissenschaft und Weiterbildung, Mainz: 1997 


\section{Endnotes}

1. That there is a predominantly uniform schooling system in Germany spite of the "multi-centralism" may be attributed to the fact that the federal states adjust and coordinate their activities in joint committees such as the Conference of Ministers of Education (Kultusministerkonferenz or KMK).

2. The habilitation or the postdoctoral lecturing qualification generally follows the DoctorateIt is usually the prerequisite for the appointment to a university professorship.

Citation Format

Kappel, Hans-Henning, Lehmann, Burkhard \& Loeper, Joachim (January, 2002) Distance Education at Conventional Universities in Germany . International Review of Research in Open and Distance Learning: 2, 2. http://www.icaap.org/iuicode?149.2.2.9 